\title{
Fruit Load Limits Root Growth, Summer Vegetative Shoot Development, and Flowering in Alternate- bearing 'Nadorcott' Mandarin Trees
}

\author{
Ockert P.J. Stander ${ }^{1}$ \\ Department of Horticultural Science, Citrus Research International (Pty) Ltd, University of \\ Stellenbosch, Private Bag X01, Matieland 7602, South Africa \\ Graham H. Barry \\ XLnT Citrus, Cape Town, South Africa \\ Paul J.R. Cronjé \\ Department of Horticultural Science, Citrus Research International (Pty) Ltd, University of \\ Stellenbosch, South Africa
}

\begin{abstract}
AdDitional Index words. carbohydrates, Citrus leaf photosynthesis, root sugars, sink strength
ABstract. The objectives of this study were to improve the understanding of the mechanism of alternate bearing and the role of carbohydrates in 'Nadorcott' mandarin (Citrus reticulata) trees. Selected phenological responses were measured in natural heavy- ("on") and low-fruiting ("off") 'Nadorcott' mandarin trees grown under commercial South African production conditions. The relationships with seasonal leaf and root carbohydrate concentrations were evaluated at the shoot-, branch- and tree level over two seasons. Fruit load $\left[R^{2}=(-) 0.80\right.$ and $R^{2}=(-) 0.73$ in seasons 1 and 2 , respectively; $\left.(P<0.01)\right]$ and the number of newly developed vegetative shoots $\left[R^{2}=0.81\right.$ and $R^{2}=0.78$ in seasons 1 and 2 , respectively; $\left.(P<0.01)\right]$ were the most important determinants of return bloom. Sprouting of a higher number of new vegetative shoots from "off" trees compared with "on" trees ("off" $=863$ and 1439 vs. "on" = 306 and 766) was not related to leaf carbohydrate concentration. Root sugar concentration peaked during full bloom and higher root growth activity was observed before a higher number of new vegetative shoots developing in "off" trees during summer. The root sugar concentration early in the season was $\approx 3$-fold lower, and root and shoot growth were absent, or lower in "on" trees compared with "off" trees. These results concur with previous research and confirm that fruit load in "on" trees inhibits summer vegetative shoot development, which manifests in poor flowering and an "off" year. This study shows that fruit are the major carbohydrate sink and probably disturb the balance between vegetative shoot development and root growth by limiting carbohydrate allocation to roots.
\end{abstract}

Alternate or biennial bearing in citrus (Citrus sp.) is the synchronized tendency of a shoot, branch, or tree to flower profusely and produce an excessive number of fruit in one season followed by a few flowers and fruit in the following season (Monselise and Goldschmidt, 1982). The alternate bearing cycle continues in subsequent seasons - seasons of heavy fruiting are referred to as "on" years, whereas seasons of low fruit numbers are called "off" years (Monselise and Goldschmidt, 1982).

Factors responsible for the initiation and maintenance of alternate bearing are complex and of a combinative nature. In certain citrus cultivars with a high tendency for alternate bearing, the phenomenon first seemed to have conspicuous causal factors, such as a high seed count and a late time of harvest (Monselise and Goldschmidt, 1982). However, reports of alternate bearing in seedless citrus cultivars \{e.g., 'Shamouti' sweet orange [Citrus sinensis (Schaffer et al., 1985)]\} and early maturing citrus cultivars $\{$ e.g., 'Satsuma' mandarin

Received for publication 24 Apr. 2018. Accepted for publication 24 May 2018. This work forms part of a PhD study which was funded by the South African Citrus Growers Association (CGA) and Citrus Research International (Pty) Ltd. The authors thank Doepie Van Zyl for providing access to orchards at Kanetvlei in De Doorns, South Africa.

${ }^{1}$ Corresponding author. E-mail: jakkie@sun.ac.za.
[Citrus unshiu (Iwasaki and Owada, 1960; Okuda, 2000)]\} provide strong discrepancies for seediness and time of harvest to be accepted as causal factors of alternate bearing. The fundamental cause(s) of alternate bearing in citrus is, therefore, still an enigma (Bangerth, 2009).

In contrast to the cause of alternate bearing, the mechanism by which alternate bearing perpetuates appears to be similar for different citrus cultivars, with the subsequent flowering response determined by the intensity of current fruiting (Martínez-Alcántara et al., 2015; Muñoz-Fambuena et al., 2011; Shalom et al., 2012, 2014; Verreynne and Lovatt, 2009). In citrus, a heavy fruit load can impose a flowering inhibition by inhibiting the sprouting of new and potential flowering sites during spring and summer (Martínez-Alcántara et al., 2015; Verreynne and Lovatt, 2009) and by restricting floral gene expression and floral bud development during flower induction (Koshita et al., 1999; Krajewski and Rabe, 1995a; MuñozFambuena et al., 2011; Shalom et al., 2012, 2014). A high number of fruit are, therefore, limiting 1) the number of new vegetative shoots and 2) their potential to undergo flower induction and transition of buds from a vegetative to reproductive phase. Although fruit load can be a factor of fruit set as influenced by environmental extremities (Hield and Hilgeman, 1969; Moss et al., 1974) or by cultural practices such as foliar application of gibberellic acid (Rivas et al., 
2006; Schaffer et al., 1985), trunk girdling (Rabe and Van Rensburg, 1996), or chemical (Agustí et al., 2002; Stander et al., 2018) or manual (Stander and Cronjé, 2016) fruit thinning, fruit load is primarily determined by the ability of a citrus tree to produce flowers (Goldschmidt and Golomb, 1982; Verreynne and Lovatt, 2009).

Studies on how fruit regulate the inhibitive effects on flowering have produced two generalized theories of alternate bearing - the hormonal theory and the nutritional theory (Bangerth, 2009; Barnett and Mielke, 1981; Davenport, 2000; Goldschmidt, 1999). The hormonal theory of alternate bearing suggests that phytohormones are responsible for floral inhibition during an "on" year (Koshita et al., 1999; MartínezAlcántara et al., 2015; Muñoz-Fambuena et al., 2011; Verreynne and Lovatt, 2009). The nutritional theory of alternate bearing, on the other hand, suggests that flowering response is determined by fruit load and availability of carbohydrates (Dovis et al., 2014; Goldschmidt and Golomb, 1982; Martínez-Alcántara et al., 2015; Monerri et al., 2011; Smith, 1976).

The primary objective of this study was to improve the understanding of the mechanism of alternate bearing in citrus using 'Nadorcott' mandarin trees. 'Nadorcott' is a latematuring mandarin cultivar that developed from a seedling of the strongly alternate-bearing 'Murcott' mandarin (Nadori, 2006) and can be prone to alternate bearing under certain South African conditions (Stander and Cronjé, 2016; Stander et al., 2017). From this premise, a further objective of this study was to establish whether any relationship exists between measurements of leaf $\mathrm{CO}_{2}$ assimilation, leaf and root carbohydrate concentrations, and tree phenological responses. To address this question, parameters of leaf gas exchange, monthly leaf and root carbohydrate concentrations, and specific phenological responses such as flowering, vegetative shoot flush, root growth, and fruit load were measured at both the tree- and shoot level in trees of contrasting fruit loads over a period of two seasons. To test these findings, leaf carbohydrate concentration and phenological events were critically evaluated in response to source/ sink manipulations in a time-course study.

\section{Materials and Methods}

Plant material and experimental site. Ten-year-old 'Nadorcott' mandarin trees budded onto 'Carrizo' citrange (C. sinensis $\times$ Poncirus trifoliata) rootstock and grown under commercial conditions were selected within an orchard with a history of alternate bearing in De Doorns (lat. $33^{\circ} 51^{\prime} \mathrm{S}$, long. $\left.19^{\circ} 52^{\prime} \mathrm{E}\right)$, Western Cape Province, South Africa in 2014.

The trees were spaced at $5 \times 2 \mathrm{~m}(1000$ trees/ha) in a sandy soil with $\mathrm{pH}_{(\mathrm{KCl})}$ 4.4. The Western Cape Province of South Africa experiences Mediterranean-type climatic conditions; summer typically occurs from December to February, autumn from March to May, winter from June to August, and spring from September to November. The region receives an annual rainfall of between 400 and $600 \mathrm{~mm}$, with the majority occurring from the end of autumn to the end of winter (May to August); i.e., winter rainfall with hot, dry summers. The orchards were cultivated, pruned, and sprayed according to recommended agricultural practices, and the trees were watered using a drip irrigation system with four emitters per tree. The total amount of water applied to each tree amounted to $\approx 4000 \mathrm{~L}$ per annum. The fertilizer rate (kilograms per hectare) was based on annual leaf mineral nutrient analysis and potential yield (kilograms fruit per hectare) and the different treatments received the same amount of fertilizer and water. Nitrogen was annually applied at a rate of $240 \mathrm{~kg} \cdot \mathrm{ha}^{-1} \mathrm{~N}$, with $25 \%$ applied as foliar, $20 \%$ as a soil application, and $55 \%$ was dissolved in the irrigation solution (fertigation) and split uniformly into applications from September to April. Most of the phosphorus and potassium were annually applied at a rate of $12 \mathrm{~kg} \cdot \mathrm{ha}^{-1} \mathrm{P}$ and $265 \mathrm{~kg} \cdot \mathrm{ha}^{-1} \mathrm{~K}$, with the majority applied via fertigation and a small fraction applied by foliar sprays.

Treatments AND EXPERIMENTAL DESIGN. The experiments were set up as a two-factor completely randomized design using whole trees [factor $1(n=10)$ ] and shoots [factor $2(n=5)$ ] as experimental units. Heavy- ("on") and low-fruiting ("off") trees were specifically selected based on their contrasting fruit loads in the previous seasons. To ensure that trees were uniformly selected, trunk circumferences of individual trees were measured and canopy volumes determined at the beginning of the experiment by measuring tree height, canopy height, and canopy radius in the north, south, east, and west directions of each tree. The canopy volume [ $V$ (cubic meters)] was calculated according to the following formula (Burger et al., 1970):

$$
V=r^{2}(\pi h-1.046 r),
$$

where $r=$ canopy radius and $h=$ height of the fruit-bearing canopy.

The same trees were used in both seasons. The alternate bearing index $(I)$ of the two treatments with contrasting fruit loads was calculated using the following formula (Gur et al., 1969):

$$
I=\frac{1}{(n-1)}\left[\frac{(a 2-a 1)}{(a 2+a 1)}+\frac{(a 3-a 2)}{(a 3+a 2)}+\ldots\right],
$$

where $n=$ number of seasons and $a=$ fruit yield in the corresponding season. The calculations in brackets are carried out ignoring signs of terms.

Branch experiments were set up in a randomized complete block design, in which a tree represented a block and a single branch represented a replication $(n=8)$. Because of a generally strong autonomous phenological growth habit of branches in mandarin trees, branches can be used to extrapolate results to alternate bearing in whole-tree scenarios (Monselise et al., 1983). All branches were located on the outside of the western side of the tree canopy at a height of $\approx 1.5 \mathrm{~m}$ above the orchard floor and had a fruit-to-leaf ratio of about one fruit per 10 leaves and an average branch circumference of $55 \mathrm{~mm}$. The following four treatments were applied to single branches in each of eight moderatebearing 'Nadorcott' mandarin trees at the end of fruit set period on 20 Nov. 2014 in summer, and in eight separate trees at the end of the fruit growth period on 22 Apr. 2015 in autumn: 1) complete defruiting of branches, 2) defruiting and girdling of branches, 3) girdling of fruiting branches, and 4) fruiting branches left intact. For the girdling treatments, a small ring of bark was removed from around the branch after making a cut with a sharp knife around the branch circumference. The branch treatments were repeated during the following season on the same dates, but on different branches. 


\section{Data collection}

Tree AND ShOOT PHENOLOGY. The number of flowers per tree was estimated by counting the number of flowers within the limits of a $0.5 \times 0.5 \times 0.5 \mathrm{~m}$ frame during full bloom in October. The tree canopy was divided into an east and west sector and an upper and lower height. Four flower counts were performed in each tree, one in each quadrant. The total number of flowers was estimated by extrapolating the mean number of flowers per frame to the total tree volume. The same procedure was used to estimate the number of new vegetative shoots after cessation of periods of vegetative shoot flush at the end of spring (November), summer (February), and autumn (April).

The phenological pattern of different shoot types in "on" and "off" trees was followed by randomly selecting five vegetative ("off") and five reproductive ("on") shoots from each tree during full bloom in October. All shoots were $\approx 12$ months of age and had triangular internodes, a length of $\approx 15 \mathrm{~cm}$, and were located on the outside of the tree canopy at a height of $\approx 1.5 \mathrm{~m}$ above the orchard floor. On each shoot, the number of nodes, the number of vegetative shoots, and total number of flowers were counted. In February and March, the numbers of persistent fruit and new vegetative shoots that developed during the subsequent vegetative shoot flushes were recorded for each shoot, and return bloom and vegetative response were determined on the same shoots during the subsequent season.

For the branch experiments, the number of new vegetative shoots and the total number of flowers were counted on branch replications after the cessation of the summer vegetative shoot flush in February and during full bloom in October.

For root growth observations, acrylic minirhizotron tubes were installed before winter in 2015 . The tubes were inserted into the soil parallel to the row direction at an angle of $45^{\circ}$ with the soil surface and to a depth of $\approx 90 \mathrm{~cm}$, thus exploring a vertical soil depth of $\approx 60 \mathrm{~cm}$. The bottoms of the tubes were sealed with a plug and the tops that protruded from the soil were capped with a white cap to reflect as much sunlight as possible and prevent water from entering. Two minirhizotron tubes, one on the eastern side and one on the western side of the tree canopy were installed below the canopy of each of one representative "on" and "off" tree. The top of the tube was located $\approx 50 \mathrm{~cm}$ from the trunk and near the canopy dripline. Digital images were captured in each tube with a root scanner (CI-600 In-Situ Root Imager; CID-BioScience, Camas, WA). Three incremental vertical color images of $21.6 \times 19.6 \mathrm{~cm}$ were captured in each minirhizotron tube and the number of new roots counted at monthly intervals. To confirm observations of the first season, additional tubes were installed in four separate "on" and "off" tree replications before Winter 2015. Root growth evaluations started at the end of Winter (August) 2016 and continued at monthly intervals.

Soil and ambient temperatures were logged throughout the study using a soil probe and air temperature logger (TinyTag ${ }^{\circledR}$ Plus 2; Gemini Data Loggers, Chichester, UK).

Fruit Yield. Commercial harvest of fruit commenced at the end of winter (in the middle of August) after fruit quality standards complied with specifications established by fruit export markets and was completed by the end of August. To determine the total fruit mass, all fruit were harvested from individual trees on the same day before the start of commercial harvest. A sample of 100 randomly collected fruit per tree was collected from each tree and the diameter of each fruit was measured with an electronic caliper. Each fruit was assigned to a fruit size category of which the average fruit weight was determined to estimate the total number of fruit per tree.

LEAF GAS EXCHANGE. In each of the five "on" and "off" shoots in eight "on" and "off" tree replications, one leaf was tagged for repeated measurements of different parameters of leaf gas exchange over the course of the experiment. The measurements in each of the five "on" and "off" shoots were pooled to represent each treatment replication $(n=8)$. The rates of leaf $\mathrm{CO}_{2}$ assimilation $\left[A_{\mathrm{c}}\left(\mu \mathrm{mol} \cdot \mathrm{m}^{-2} \cdot \mathrm{s}^{-1} \mathrm{CO}_{2}\right)\right]$, leaf stomatal conductance $\left[g_{\mathrm{s}}\left(\mathrm{mmol} \cdot \mathrm{m}^{-2} \cdot \mathrm{s}^{-1}\right)\right]$, and leaf transpiration $[E$ $\left.\left(\mathrm{mmol} \cdot \mathrm{m}^{-2} \cdot \mathrm{s}^{-1} \mathrm{H}_{2} \mathrm{O}\right)\right]$ were measured at monthly intervals on selected cloudless days using a portable infrared gas analyzer (LI-6400; LI-COR, Lincoln, NE). Data collection started at $\approx 0800 \mathrm{HR}$ and was completed between 1100 and $1200 \mathrm{HR}$ on each measurement date. Measurements were conducted using a closed chamber. The airflow rate was set at $300 \mu \mathrm{mol} \cdot \mathrm{s}^{-1}$, photosynthetic photon flux of $800 \mu \mathrm{mol} \cdot \mathrm{m}^{-2} \cdot \mathrm{s}^{-1}$, and the block temperature at $25{ }^{\circ} \mathrm{C}$, with controlled $\mathrm{CO}_{2}$ concentration of $380 \mathrm{mg} \cdot \mathrm{L}^{-1}$.

LEAF AND ROOT CARBOHYDRATES. A sample consisting of eight leaves was collected from each "on" and "off" tree replication between 0900 and $1000 \mathrm{HR}$ at monthly intervals and from branch replications on the day of treatment and at 2 -week intervals for 6 weeks after treatment. The eight leaves consisted of two leaves sampled from each of four vegetative shoots. Only mature leaves were sampled from the third to fifth position on fully hardened, nonfruiting, and purely vegetative shoots. The spring leaf samples were collected from vegetative shoots that developed during the previous season's vegetative shoot flushes, the summer leaf samples were collected from vegetative shoots that developed during the current season's spring vegetative shoot flush, and the autumn and winter leaf samples were collected from vegetative shoots that developed during the current season's summer vegetative shoot flush. A sample of fine fibrous roots $(<0.5 \mathrm{~mm}$ diameter) was collected from representative, pooled root tissues that were sampled from four different areas around the trunk of each tree. The root and leaf samples were washed with distilled water, frozen at $-80{ }^{\circ} \mathrm{C}$ and freezedried (Christ Beta 1-8 LD Freeze Dryer; Martin Christ Gefriertrocknungsanlagen, Osterode am Harz, Germany), before being ground to a fine powder with an analytical grinder (Yellow line A10; IKA-Werke, Staufen, Germany).

Total sugars were extracted from $100 \mathrm{mg}$ of each dried leaf and root sample with $5 \mathrm{~mL} 80 \%(\mathrm{v} / \mathrm{v})$ ethanol at $80{ }^{\circ} \mathrm{C}$ for $1 \mathrm{~h}$. The extraction process was repeated twice following the first extraction and the respective supernatants pooled. The pellets were then extracted three times with $5 \mathrm{~mL}$ deionized water at $80{ }^{\circ} \mathrm{C}$ for $24 \mathrm{~h}$ for the determination of total water-soluble polysaccharides. Total starch was determined from the remaining pellet by quantifying the glucose released following an enzymatic digestion of the residue for $17 \mathrm{~h}$ at $60^{\circ} \mathrm{C}$, with the amyloglucosidase enzyme [AMG (Sigma Aldrich, Aston Manor, South Africa)].

The $80 \%$ ethanol, water, and AMG enzyme extracts were analyzed for total soluble sugars using the phenol-sulfuric acid assay (Brummer and Cui, 2005). Briefly, a volume of $20 \mu \mathrm{L}$ of each of the respective extracts was added to $180 \mu \mathrm{L}$ deionized water, $200 \mu \mathrm{L}$ phenol $\left(5 \mathrm{~mL} \cdot \mathrm{L}^{-1}\right)$, and $1000 \mu \mathrm{L}$ concentrated 
sulfuric acid. Absorbance was determined on a spectrophotometer (Cary 50 Series; Varian, Mulgrave, Australia) at $490 \mathrm{~nm}$, precisely after $30 \mathrm{~min}$ against a blank prepared for the standard. A standard curve for glucose concentrations was prepared by diluting $0,50,100,150$, and $200 \mu \mathrm{L}$ glucose stock solution $\left(0.10 \mathrm{mg} \cdot \mathrm{mL}^{-1}\right)$ with deionized water to a final volume of $200 \mu \mathrm{L}$. The sugar concentrations were expressed as milligrams per gram leaf or root dry weight (DW) and are respectively referred to as sugar concentration, polysaccharide concentration, and starch concentration.

Statistical anAlysis. STATISTICA data analysis software (2015; Dell, Round Rock, TX) was used to analyze the data. Analysis of variance (ANOVA) or repeated-measures ANOVA was performed when responses were repeated on the same respondent. Mean separations were carried out using Fisher's least significant difference test, where applicable, at $P \leq 0.05$. Relationships between two continuous variables were analyzed by regression analysis and the strength of the relationship indicated by Spearman's correlation coefficient. The percentage variation explained is $100 \times R^{2}$, which is indicated as $(-) R^{2}$ if the correlation was negative.

\section{Results}

Tree Phenology. The first period of vegetative shoot flush, which coincided with the sprouting of inflorescences (i.e., the spring flush), started $\approx 2$ weeks after harvest at the end of August and continued for 8 weeks until full bloom in spring, during the third week of October (Fig. 1A). The second period of vegetative shoot flush, i.e., the summer flush, started in the middle of January and continued until the end of summer (February), with "off" trees sprouting significantly more summer vegetative shoots than "on" trees (Table 1; Fig. 1D). A third, short period of vegetative shoot flush occurred at the start of autumn (end of March), i.e., the autumn flush (Fig. 1F), but these flush measurements were combined with those of the summer flush as they contributed very little to the total number of newly developed vegetative shoots and no significant differences were recorded between treatments (data not shown). Nevertheless, the number of total new vegetative shoots that developed in "off" trees was almost double that in "on" trees in both seasons ["off" $=863$ and 1439 shoots vs. "on" = 306 and 766 shoots (Table 1)].

Intensity of return bloom flowering had an inverse relationship with fruit yield in both seasons (Table 1). The flowering response of the 10 "off" trees of 2014 (season 1) was significantly and $\approx 2$-fold higher than that of the "on" trees ("off" = 51,097 flowers/tree vs. "on" = 30,034 flowers/tree); however, in season 2, return bloom of the "off" trees was $\approx 230$-fold higher than that of the "on" trees ("off" $=37,712$ flowers/tree vs. "on" = 165 flowers/tree).

Monthly monitoring of the root zones of five "on" and "off" trees indicated one major period of root growth during summer and a shorter period of root growth during early autumn (Figs. 1C, 1E, and 2). Vegetative shoot flush and root growth showed alternating growth patterns in "off" trees and the first period of root flush started during early summer (November) after cessation of the first vegetative shoot flush in spring (Fig. 1C). This root flush peaked in midsummer (December), with "off' trees showing a more intense root flush compared with "on" trees, in which new root growth was almost completely absent (Fig. 2). A second period of root flush started in autumn (end of March), but during winter (from May onward), no new root growth was observed (Figs. $1 \mathrm{E}$ and 2). Interestingly, root growth on the western side of the tree was more pronounced than that of the eastern side of the tree, for both "on" and "off" trees (Fig. 2).

Shoot Phenology. In both "on" and "off" trees, "on" shoots sprouted significantly fewer new vegetative shoots during spring than "off" shoots in both seasons (Tables 2 and 3). However, tree fruiting status ("on"/off") influenced the number of new vegetative shoots that sprouted on individual shoots during the spring of season 1, with "off" shoots in "off" trees sprouting significantly more new vegetative shoots during spring, compared with "off" shoots in "on" trees (Table 2).

Tree fruit load significantly affected the number of new vegetative shoots that sprouted from different shoot types during summer. "Off" shoots sprouted significantly more vegetative shoots during summer than "on" shoots, and "off" shoots from "off" trees sprouted significantly more summer vegetative shoots than "off" shoots from "on" trees (Table 2).

The higher number of total new vegetative shoots that developed on "off" shoots in "off" trees during season 1 significantly affected the number of nodes and potential flowering positions during the subsequent season (Table 3). "Off" shoots from "off" trees had more available nodes and potential sites for flower development in the following season than "off" shoots from "on" trees (27.6 vs. 18.2), and therefore, produced significantly more flowers during the subsequent spring than "off" shoots from "on" trees and "on" shoots from "off" trees (Table 3).

Fruit Yield. The 10 selected "off" trees during 2014 (season 1) showed a strong alternate bearing habit $[I=0.77$ (Table 4)] and their fruit yields fluctuated severely between seasons (Table 1). However, "on" trees did not show a clear alternate bearing habit in 2014 [ $I=0.08$ and 0.15 (Table 4$)]$, and their fruit yields decreased over the following two seasons (Table 1). However, the fruit yields of the two treatments differed in each season and provided a sufficient contrast to evaluate any significance between treatments in each season. Fruit yield of the 10 "off" trees of 2014 (season 1) was significantly and $\approx 7$-fold lower than that of the "on" trees ("off" = 126 fruit/tree vs. "on" = 918 fruit/tree); however, in season 2 , fruit yield of the "off" trees was only $\approx 2$-fold lower than that of that of the "on" trees ("off" $=657$ fruit/tree vs. "on" = 1225 fruit/tree) (Table 1).

LeAF GAS EXCHANGE. Apart from some anomalies, leaf $A_{\mathrm{c}}, g_{\mathrm{s}}$, and $E$ were always higher in "on" shoots than in "off" shoots (Tables 5 and 6). With the exception of December in season 1, leaf $A_{\mathrm{c}}$ was significantly higher in "on" trees than in "off" trees throughout spring and summer in both seasons and in the middle of spring (October) and summer (December) of season 1, for "on" shoots compared with "off" shoots (Tables 5 and 6). However, in December of season 1, $A_{\mathrm{c}}$ of leaves representing different shoot types was significantly influenced by tree fruiting status - there were no significant differences in $A_{\mathrm{c}}$ between leaves from different shoot types in "off" trees, and "on" shoots in "on" trees; however, $A_{\mathrm{c}}$ of leaves from "off" shoots in "on" trees was significantly lower than those of other shoot types (Table 5).

During spring of season 1, and spring and summer of season 2 , leaf $g_{\mathrm{s}}$ was significantly higher in "on" trees than that of "off" trees and significantly higher in "on" shoots than that of 


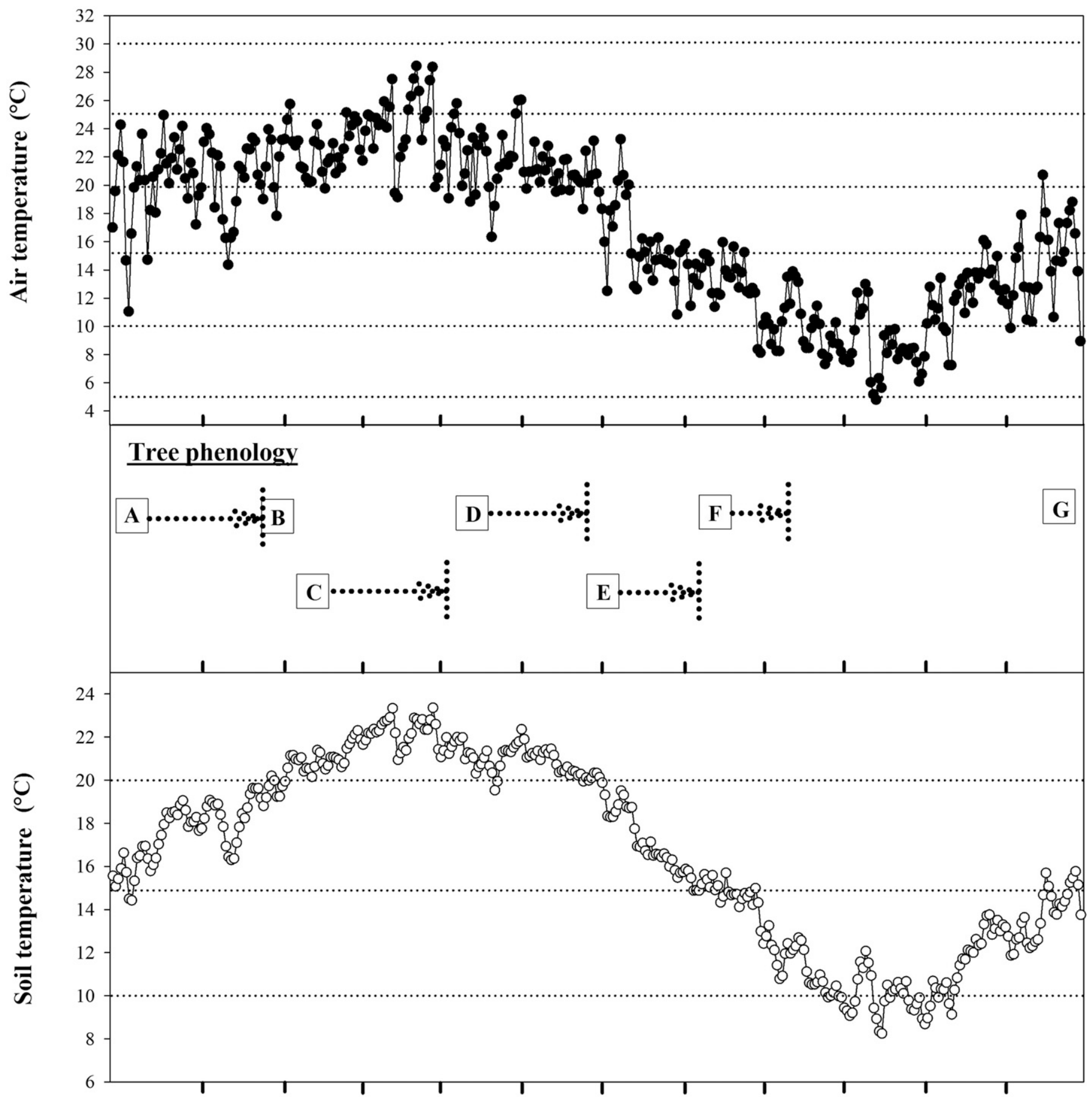

$\begin{array}{llllllllll}\text { Sept. } 2014 & \text { Oct. } 2014 & \text { Nov. } 2014 & \text { Dec. } 2014 & \text { Jan. } 2015 & \text { Feb. } 2015 & \text { Mar. } 2015 & \text { Apr. } 2015 & \text { May } 2015 & \text { June } 2015 \\ \text { July } 2015 & \text { Aug. } 2015\end{array}$

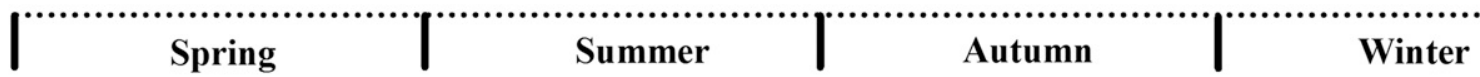

Fig. 1. Daily average air temperature, tree phenological events, and soil temperature in a 'Nadorcott' mandarin orchard in De Doorns, Western Cape Province, South Africa. Tree phenology: (A) first vegetative shoot flush in spring, (B) full bloom, (C) first root flush, (D) second vegetative shoot flush in summer, (E) second root flush, (F) third vegetative shoot flush in autumn, and (G) harvest. Temperatures were logged throughout the study using a soil probe and air temperature logger (TinyTag ${ }^{\circledR}$ Plus 2; Gemini Data Loggers, Chichester, UK).

"off" shoots in the middle of spring (October) of season 1 (Tables 5 and 6). However, in December of season $1, g_{\mathrm{s}}$ of leaves representing different shoot types was significantly influenced by tree fruiting status-there were no significant differences in $g_{\mathrm{s}}$ between leaves from different shoot types in "off" trees and "on" shoots in "on" trees; however, $g_{\mathrm{s}}$ of leaves from "off" shoots in "on" trees were significantly lower than that of other shoot types (Table 5).

During spring (October and November) of season 1 and during spring and summer of season 2, leaf $E$ was significantly 
Table 1. Total fruit yield, vegetative response, and return bloom of 10-year-old alternate-bearing 'Nadorcott' mandarin trees over three seasons.

\begin{tabular}{|c|c|c|c|c|c|c|}
\hline \multirow[b]{3}{*}{ Tree fruiting status } & \multirow{3}{*}{$\begin{array}{l}\text { Fruit yield in the } \\
\text { current yr (kg/tree) }\end{array}$} & \multirow[b]{2}{*}{$\begin{array}{l}\text { Fruit yield in } \\
\text { the current yr }\end{array}$} & \multicolumn{4}{|c|}{ Return bloom and vegetative response in the following yr } \\
\hline & & & Flowers & $\begin{array}{c}\text { New spring } \\
\text { vegetative shoots }\end{array}$ & $\begin{array}{c}\text { New summer } \\
\text { vegetative shoots }\end{array}$ & $\begin{array}{c}\text { Total new } \\
\text { vegetative shoots }\end{array}$ \\
\hline & & & & (no./tree) & & \\
\hline “Off" & $14 b^{z}$ & $126 \mathrm{~b}$ & $51,097 \mathrm{a}$ & $163 \mathrm{~b}$ & $144 \mathrm{~b}$ & $306 \mathrm{~b}$ \\
\hline “On” & $84 \mathrm{a}$ & 918 a & $30,034 \mathrm{~b}$ & $493 \mathrm{a}$ & 369 a & $863 \mathrm{a}$ \\
\hline$P$ value & $<0.01$ & $<0.01$ & $<0.01$ & $<0.01$ & $<0.01$ & $<0.01$ \\
\hline “On” & $110 \mathrm{a}$ & $1,225 \mathrm{a}$ & $165 \mathrm{~b}$ & 1018 a & $420 \mathrm{a}$ & 1,439 a \\
\hline "Off" & $71 \mathrm{~b}$ & $657 \mathrm{~b}$ & $32,712 \mathrm{a}$ & $598 \mathrm{~b}$ & $167 \mathrm{~b}$ & $766 \mathrm{~b}$ \\
\hline$P$ value & $<0.01$ & $<0.01$ & $<0.01$ & $<0.01$ & $<0.01$ & $<0.01$ \\
\hline \multicolumn{7}{|l|}{ Season 3} \\
\hline “'Off” & $16 \mathrm{~b}$ & $144 \mathrm{~b}$ & & & & \\
\hline “On" & $52 \mathrm{a}$ & $621 \mathrm{a}$ & & & & \\
\hline
\end{tabular}

${ }^{\mathrm{z}}$ Different letters in the same column denote significant differences via Fisher's least significant difference test at $P \leq 0.05(n=10)$.

higher in "on" trees than that of "off" trees and significantly higher in "on" shoots than that of "off" shoots in the middle of spring (October) of season 1 (Tables 5 and 6). During early summer (December) of season 1 , leaf $E$ was significantly higher in "off" trees than that in "on" trees and similar for different treatments in January (Table 5).

LEAF AND ROOT CARBOHYDRATES. Over the two seasons, leaf sugar concentration showed different seasonal patterns of accumulation-leaf sugar concentration peaked during spring of season 1 , but in season 2 , it only started to increase in winter (Fig. 3A). In both seasons, leaf sugar concentration was similar for "on" and "off" trees in spring
(September and October), but leaf sugar concentration was significantly higher in "off" trees from the end of spring to winter (November to June) in season 1 (Fig. 3A). In season 2, there were no significant differences in leaf sugar concentration between "on" and "off" trees at any time (Fig. 3A).

In both seasons, leaf polysaccharide concentration peaked during spring and was significantly higher in "off" trees in spring (October of season 1 and September of season 2) (Fig. 3B). Except for "off" trees having significantly higher leaf polysaccharide concentration during autumn (March) and winter (June) of season 2, the leaf polysaccharide concentration
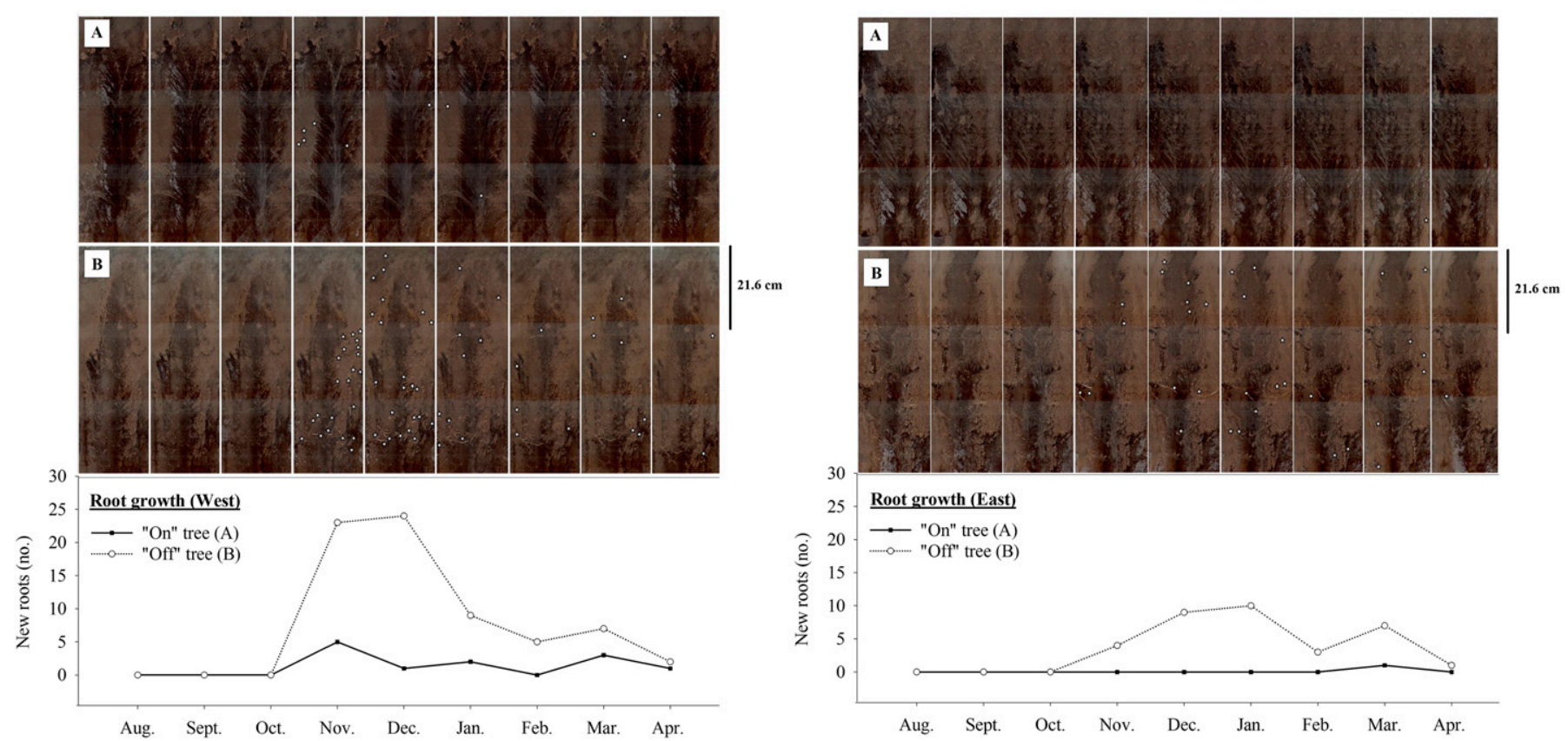

Fig. 2. The pattern of root growth activity on the western (left) and eastern (right) side of the tree canopy of 10-year-old alternate-bearing 'Nadorcott' mandarin trees with contrasting fruit loads [(A) “on" tree and (B) "off" tree]. Minirhizotron tubes were installed before Winter 2015 with evaluations starting in Aug. 2016 and continued at monthly intervals. Digital images were captured in each tube with a root imager (CI-600 In Situ Root Scanner; CID-BioScience, Camas, WA). Three incremental, vertical images were captured down each minirhizotron tube and new roots were counted at monthly intervals. A star indicates a new root within each observation. 
Table 2. The phenological pattern of different shoot types ("on" or "off") in 10-year-old alternate-bearing 'Nadorcott' mandarin trees during season 1.

\begin{tabular}{|c|c|c|c|c|c|c|}
\hline & Nodes & $\begin{array}{c}\text { New spring } \\
\text { vegetative shoots }\end{array}$ & Dormant buds & Flowers & Fruit & $\begin{array}{c}\text { New summer } \\
\text { vegetative shoots }\end{array}$ \\
\hline Treatment & \multicolumn{6}{|c|}{ (no./shoot) } \\
\hline \multicolumn{7}{|l|}{ Tree } \\
\hline “Off” trees & 10.6 & - & 6.7 & - & 0.7 & - \\
\hline \multicolumn{7}{|l|}{ Shoot } \\
\hline "On" shoots & 11.4 & - & $5.6 \mathrm{~b}^{\mathrm{z}}$ & - & $1.5 \mathrm{a}$ & - \\
\hline \multicolumn{7}{|l|}{ Tree $\times$ shoot } \\
\hline "On" trees $\times$ "on" shoots & - & $0.1 \mathrm{c}$ & - & $12.7 \mathrm{a}$ & - & $0.3 \mathrm{c}$ \\
\hline "On" trees $\times$ "off" shoots & - & $1.9 \mathrm{~b}$ & - & $0.7 \mathrm{c}$ & - & $1.2 \mathrm{~b}$ \\
\hline "Off" trees $\times$ “on" shoots & - & $0.7 \mathrm{c}$ & - & $6.4 \mathrm{~b}$ & - & $0.5 \mathrm{c}$ \\
\hline "Off" trees $\times$ “off" shoots & - & $3.2 \mathrm{a}$ & - & $0.5 \mathrm{c}$ & - & $3.5 \mathrm{a}$ \\
\hline \multicolumn{7}{|l|}{$P$ value } \\
\hline
\end{tabular}

${ }^{\mathrm{z}}$ Different letters in the same column denote significant differences via Fisher's least significant difference test at $P \leq 0.05$ ( $\left.n=10\right)$. If significant interaction occurred between tree and shoot, only values for interaction are shown.

Table 3. The phenological pattern of different shoot types ("on" or "off") in 10-year-old alternate-bearing 'Nadorcott' mandarin trees during season 2.

\begin{tabular}{|c|c|c|c|c|c|}
\hline \multirow[b]{2}{*}{ Treatment } & Nodes & $\begin{array}{c}\text { New spring } \\
\text { vegetative shoots }\end{array}$ & Dormant buds & Flowers & Fruit \\
\hline & \multicolumn{5}{|c|}{ (no./shoot) } \\
\hline \multicolumn{6}{|l|}{ Tree } \\
\hline "Off" trees & - & 3.3 & 7.1 & - & 1.4 \\
\hline "On" trees & - & 2.6 & 8.0 & - & 1.4 \\
\hline \multicolumn{6}{|l|}{ Shoot } \\
\hline "Off" shoots & - & $4.3 \mathrm{a}^{\mathrm{z}}$ & 6.9 & - & $0.9 \mathrm{~b}$ \\
\hline "On” shoots & - & $1.6 \mathrm{~b}$ & 8.1 & - & $2.0 \mathrm{a}$ \\
\hline \multicolumn{6}{|l|}{ Tree $\times$ shoot } \\
\hline "Off" trees $\times$ "off" shoots & $11.4 \mathrm{c}$ & - & - & $1.92 \mathrm{c}$ & - \\
\hline "Off" trees $\times$ “on" shoots & $18.2 \mathrm{~b}$ & - & - & $5.70 \mathrm{~b}$ & - \\
\hline “On" trees $\times$ "off" shoots & $12.3 \mathrm{c}$ & - & - & $1.32 \mathrm{c}$ & - \\
\hline "On" trees $\times$ "on" shoots & $27.6 \mathrm{a}$ & - & - & $24.43 \mathrm{a}$ & - \\
\hline \multicolumn{6}{|l|}{$P$ value } \\
\hline Tree & 0.03 & 0.29 & 0.16 & 0.02 & 0.90 \\
\hline Shoot & $<0.01$ & $<0.01$ & 0.05 & $<0.01$ & $<0.01$ \\
\hline Tree $\times$ shoot & 0.02 & 0.29 & 0.80 & 0.01 & 0.07 \\
\hline
\end{tabular}

${ }_{\mathrm{z}}$ Different letters in the same column denote significant differences via Fisher's least significant difference test at $P \leq 0.05(n=10)$. If significant interaction occurred between tree and shoot, only values for interaction are shown.

of "on" and "off" trees remained similar throughout the rest of the season (Fig. 3B).

Leaf starch concentration of both treatments peaked during spring (September) in both seasons and decreased toward winter (Fig. 3C). In both seasons, leaf starch concentration in September was higher for "on" trees, but from the middle of spring to the middle of winter (October to June), leaf starch concentration in "off" trees was significantly higher than that in "on" trees (Fig. 3C).

Throughout season 1, the major carbohydrate component in roots of "off" trees was sugar, whereas the major carbohydrate component in roots of "on" trees was starch (Fig. 4). Root sugar concentration during spring was significantly higher in roots of "off" trees (Fig. 3E). Root sugar concentration in "off" trees increased substantially from spring (September to October) and after full bloom, decreased rapidly and was significantly lower than "on" trees by the start of summer (November) (Fig. 3E). Throughout the rest of summer and in winter (June), the root sugar concentration in "off" trees was significantly higher than that of "on" trees (Fig. 3E). In the middle of spring (October) of season 2, the root sugar concentration in "off" trees was again significantly higher than that in "on" trees and showed a distinct increase from the start of spring (from September to October), followed by a rapid decrease by the end of spring (November) (Fig. 3E). For the rest of season 2, a similar pattern of root sugar concentration was evident compared with season 1 , but differences were not consistently significant between treatments (Fig. 3E).

In season 1, root polysaccharide concentration remained relatively stable in "off" trees; however, in "on" trees, root polysaccharide concentration increased at the end of spring (November), peaked in summer (December), and remained significantly higher until winter (June) (Fig. 3F). A similar pattern was evident in season 2, except for a nonsignificant difference in root polysaccharide concentration between "on" and "off" trees in winter (June) (Fig. 3F).

Root starch concentration was similar for "on" and "off" trees during spring (September) of season 1, but from spring 
(October) to autumn (March), root starch concentration in "on" trees was significantly higher than root starch concentration in "off" trees (Fig. 3G). From the end of winter to spring (June to September), root starch concentration was significantly higher in "off" trees, but for the rest of season 2, root starch concentration in "on" and "off" trees was similar and any significant differences were erratic (Fig. 3G).

BRANCH MANIPULATIONS. The summer vegetative response to defruiting + girdling and defruiting alone was significantly higher than that to the fruiting + girdling and the fruiting treatments (Table 7). During summer, leaf sugar concentration decreased in response to defruiting + girdling and remained significantly lower than the other treatments throughout the experiment, except for December (Table 8). There were no significant differences in leaf sugar concentration between girdling, defruiting, and fruiting treatments throughout the experiment. Polysaccharide and starch concentrations in the leaves increased in response to defruiting + girdling and remained significantly higher than the other treatments throughout the experiment (Table 8).

The flowering response to the combination of defruiting and girdling was significantly higher than that of the other treatments

Table 4. Total fruit yield and alternate bearing index (I) of 10-year-old alternate-bearing 'Nadorcott' mandarin trees.

\begin{tabular}{lllllll}
\hline & \multicolumn{2}{c}{ Tree fruit yield $(\mathrm{kg} /$ tree $)$} & & \multicolumn{2}{c}{$I^{z}$} \\
\cline { 2 - 4 } Treatment & 2014 & 2015 & 2016 & & $2014-15$ & $2015-16$ \\
\hline "Off" tree 2014 & $14 \mathrm{~b}^{\mathrm{y}}$ & $110 \mathrm{a}$ & $16 \mathrm{~b}$ & & $0.77 \mathrm{a}$ & $0.77 \mathrm{a}$ \\
"On" tree 2014 & $84 \mathrm{a}$ & $71 \mathrm{~b}$ & $52 \mathrm{a}$ & & $0.08 \mathrm{~b}$ & $0.15 \mathrm{~b}$ \\
$P$ value & $<0.01$ & $<0.01$ & $<0.01$ & $<0.01$ & $<0.01$
\end{tabular}

${ }^{\mathrm{z}}$ The alternate bearing index $(I)$ was calculated using the following formula (Gur et al., 1969): $I=\frac{1}{(n-1)}\left[\frac{(a 2-a 1)}{(a 2+a 1)}+\frac{(a 3-a 2)}{(a 3+a 2)}+\ldots\right]$ where $n=$ number of seasons and $a=$ fruit yield in the corresponding season. The calculations in brackets are carried out ignoring signs of terms.

${ }^{\mathrm{y}}$ Different letters in the same column denote significant differences via Fisher's least significant difference test at $P \leq 0.05(n=10)$.
(Table 7). During winter, leaf sugar concentration 2 and 6 weeks after treatment was significantly lower in the combined defruiting and girdling treatment than that of the other treatments (Table 8). There were no significant differences between leaf sugar concentration of the girdling, defruiting, and fruiting treatments, 2, 4, and 6 weeks after treatments (Table 8). Polysaccharide and starch concentrations in the leaves increased significantly in response to defruiting and girdling and remained significantly higher than the other treatments from 4 to 6 weeks after treatment (Table 8). There were no significant differences in leaf sugar concentration between girdling, defruiting, and fruiting treatments throughout the experiment, except for 6 weeks after treatment, when the fruiting treatment had a significantly lower leaf sugar concentration than girdling and defruiting treatments (Table 8).

\section{Discussion}

Fruit load in 'Nadorcott' mandarin trees was the central factor in determining the number of flowers in the subsequent season $\left[R^{2}=(-) 0.80\right.$ and $R^{2}=(-) 0.73$ in seasons 1 and 2 , respectively $(P<0.001)]$. The number of flowers and fruit load also had a strong inverse relationship with the number of new vegetative shoots in spring $\left[R^{2}=(-) 0.80\right.$ and $R^{2}=(-) 0.79$ in seasons 1 and 2 , respectively $(P<0.001)]$, summer $\left[R^{2}=\right.$ $(-) 0.81$ and $R^{2}=(-) 0.78$ in seasons 1 and 2 , respectively $(P<$ $0.001)]$, and with total new vegetative shoots $\left[R^{2}=(-) 0.79\right.$ and $R^{2}=(-) 0.85$ in seasons 1 and 2 , respectively $\left.(P<0.001)\right]$. The number of new vegetative shoots that developed in "off" trees was 2- to 3-fold higher in spring and summer, and the number of total new vegetative shoots that developed in "off" trees was almost double that in "on" trees ("off" = 863 and 1439 shoots vs. "on" = 306 and 766 shoots). Fewer new vegetative shoots developed when fruit load was high, i.e., in "on" trees than when fruit load was low, i.e., in "off" trees. These results concur with those from previous studies in citrus (García-Luís et al., 1995b; Krajewski and Rabe, 1995b; Lenz, 1967; Martínez-Alcántara et al., 2015; Monselise and Goldschmidt, 1982; Southwick and

Table 5. The rates of photosynthesis, stomatal conductance $\left(g_{\mathrm{S}}\right)$, and transpiration of leaves from different shoot types ("on" or "off") in 10-yearold alternate-bearing 'Nadorcott' mandarin trees during summer of season 1.

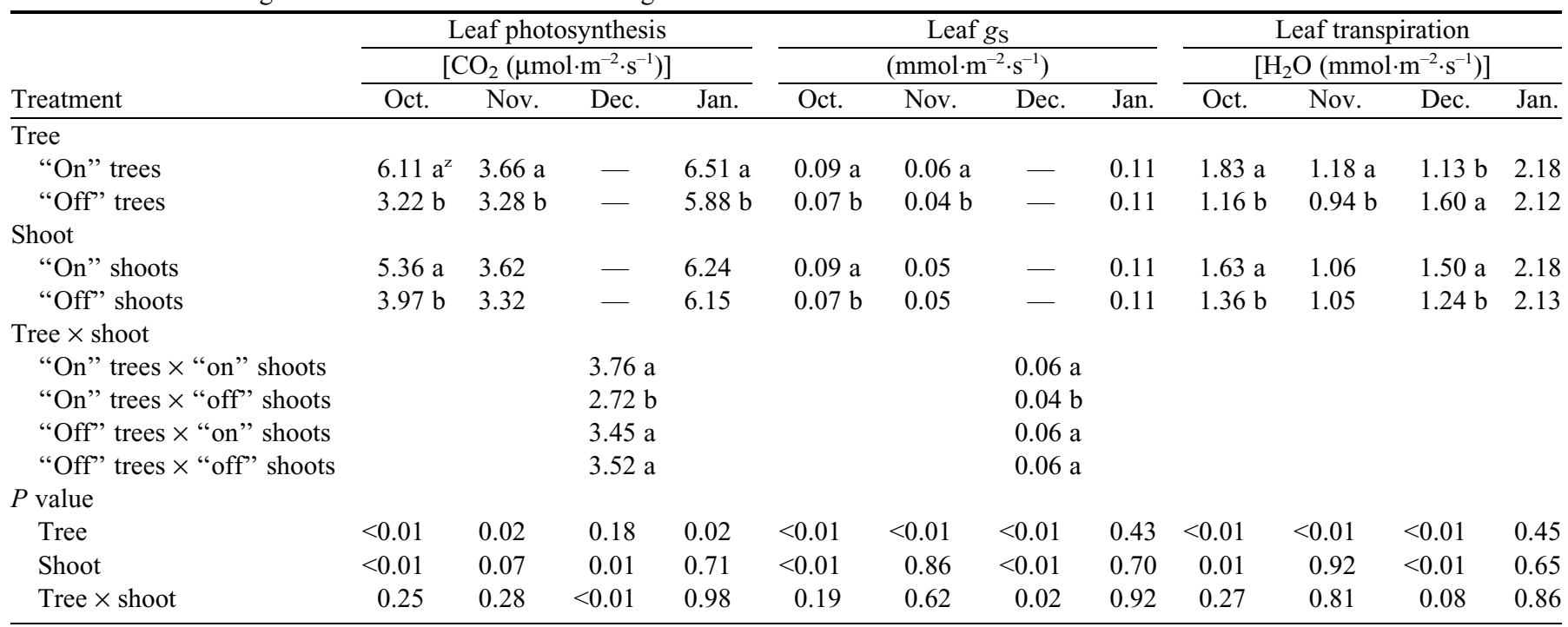

${ }_{\mathrm{z}}$ Different letters in the same column denote significant differences via Fisher's least significant difference test at $P \leq 0.05(n=8)$. If significant interaction occurred between tree and shoot, only values for interaction are shown. 
Table 6. The rates of photosynthesis, stomatal conductance $\left(g_{\mathrm{S}}\right)$ and transpiration of leaves in different shoot types ("on" or “off”) in 10-year-old alternate-bearing 'Nadorcott' mandarin trees during summer of season 2.

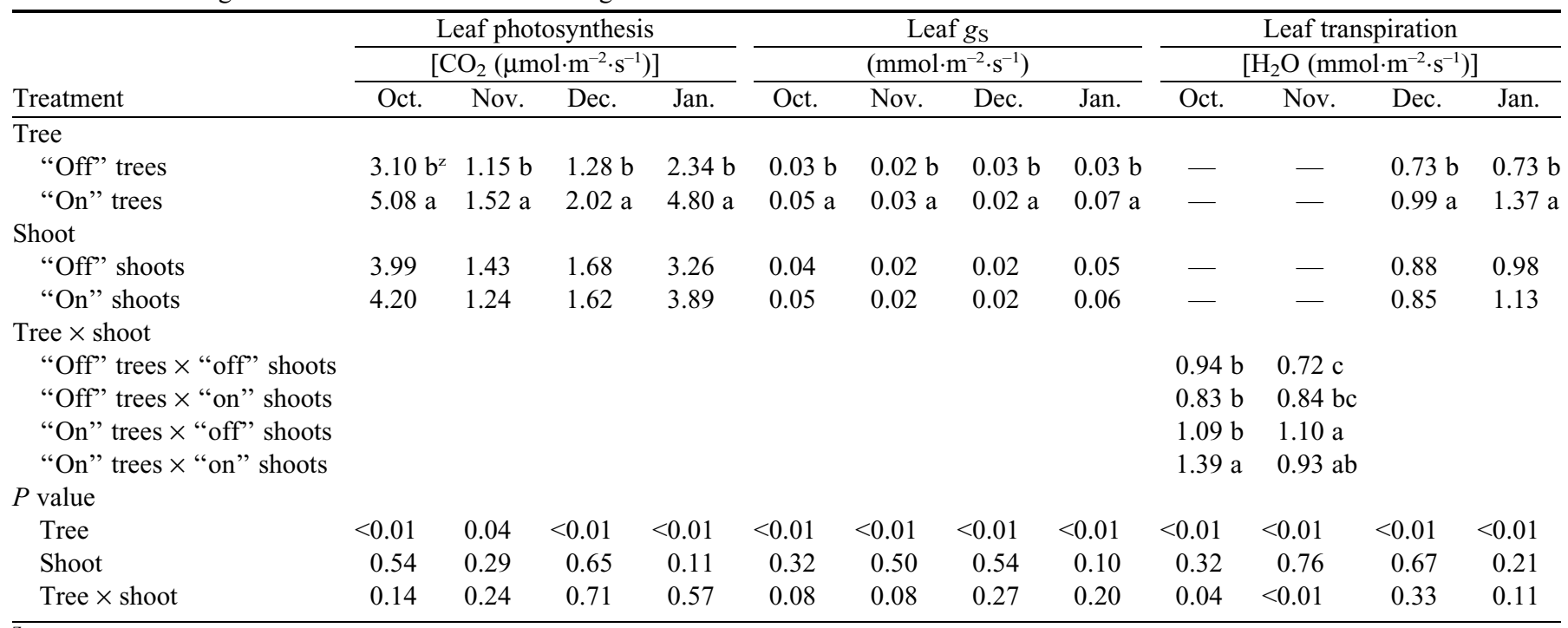

${ }_{\mathrm{z}}$ Different letters in the same column denote significant differences via Fisher's least significant difference test at $P \leq 0.05$ ( $n=8$ ). If significant interaction occurred between tree and shoot, only values for interaction are shown.

Davenport, 1987; Verreynne and Lovatt, 2009) and with studies in other alternate-bearing evergreens; e.g., in olive [Olea europaea (Dag et al., 2010)]. The higher number of new vegetative shoots in "off" trees affected flowering in the subsequent spring; "off" trees had more nodes and more potential sites available from which a flower could develop. Hence, tree flower number was $\approx 2$-fold higher in "off" trees in spring of season 1 ("off" = 51,097 flowers/tree vs. "on" $=30,034$ flowers/tree) and $\approx 230$ fold higher in spring of season 2 ("off" $=37,712$ flowers/tree vs. "on" = 165 flowers/tree).

The inhibition of the vegetative shoot flush and return bloom by fruit load was unrelated to parameters of leaf gas exchange or to leaf carbohydrate concentration. Fruit were the biggest carbohydrate sink, and apart from some anomalies, photosynthesis, $g_{\mathrm{s}}$, and transpiration rates during spring and summer were always higher in leaves in "on" shoots and "on" trees, from which fewer new vegetative shoots developed, than in "off" shoots in "off" trees, which was unsurprising (Syvertsen et al., 2003). However, the relationship between leaf sugar concentration and the number of new spring and summer vegetative shoots was nonsignificant and very weak. Because of a higher starch concentration in leaves in "off" trees than in "on" trees [season 1: 98 vs. $72 \mathrm{mg} \cdot \mathrm{g}^{-1}$ leaf DW $(P<0.0001)$; season 2: 53 vs. $42 \mathrm{mg} \cdot \mathrm{g}^{-1}$ leaf DW $\left.(P<0.0001)\right]$, leaf starch concentration and the number of new vegetative shoots had a stronger relationship in summer [season 1: $R^{2}=0.53(P=$ $0.040)$; season 2: $\left.R^{2}=0.71(P<0.001)\right]$. However, when testing the significance of the apparent relationship using branch experiments, results failed to provide confirmation of the treelevel results. When fruiting branches were girdled, leaf carbohydrate concentration increased $\approx 3$-fold compared with nonfruiting branches [298 vs. $112 \mathrm{mg} \cdot \mathrm{g}^{-1}$ leaf DW $(P<0.0001)$ ], but very few new vegetative shoots sprouted per branch compared with nonfruiting branches $[1.6$ vs. 8.6 shoots $(P=0.0021)]$ and carbohydrates accumulated in leaves to toxic levels (Stander et al., 2017). The overall inhibition of summer vegetative shoot development in "on" trees appears to be regulated by the presence of fruit and an endogenous regulator other than carbohydrates (Malik et al., 2015; Verreynne, 2005; Verreynne and Lovatt, 2009).

Besides more flowering positions, flowering intensity was consistently higher in "off" shoots in "off" trees, than in "off" shoots in "on" trees. From "off" shoots in "off" trees, $\approx 50 \%$ more nodes developed than from "off" shoots in "on" trees and, additionally, flower intensity in "off" shoots in "off" trees (i.e., the number of flowers that sprouted from a single node in an individual shoot) was $\approx 5$-fold that of "off" shoots in "on" trees. "Off" shoots in "off" trees had higher leaf carbohydrate concentrations throughout the flower induction period and sprouted a higher number of flowers than "off" shoots in "on" trees, where fruit were also absent, but fruit load of the tree was higher and leaf carbohydrate concentration lower. Winter leaf starch concentration was, therefore, negatively correlated with fruit yield in both seasons and positively with return bloom $\left[R^{2}=0.68\right.$ and $R^{2}=0.82$ in seasons 1 and 2 , respectively $(P<0.001)]$. This flowering response to high leaf starch concentration during winter may be purely coincidental, but similarly, at the branch level, an $\approx 2$-fold elevation of leaf carbohydrate concentration by girdling during the corresponding period increased return bloom flowering $\approx 2$-fold in the absence of fruit compared with branches where fruit were also absent, but leaf carbohydrate concentrations were lower. This effect of winter leaf carbohydrate concentration on flowering appears to manifest independent of the number of newly available shoots and a localized effect of fruit presence on a shoot or branch, but by the effects an "on" crop has on plant available energy.

Apart from fruit load, the number of newly developed vegetative shoots - the most important determinant of return bloom flowering and subsequent fruit load in this studycorrelated with the level of root growth activity. In "on" trees, root growth was almost completely absent and the development of new vegetative shoots was halved. By contrast, two distinct peaks of root growth and three vegetative shoot flushes occurred in a synchronized pattern in "off" trees. The 


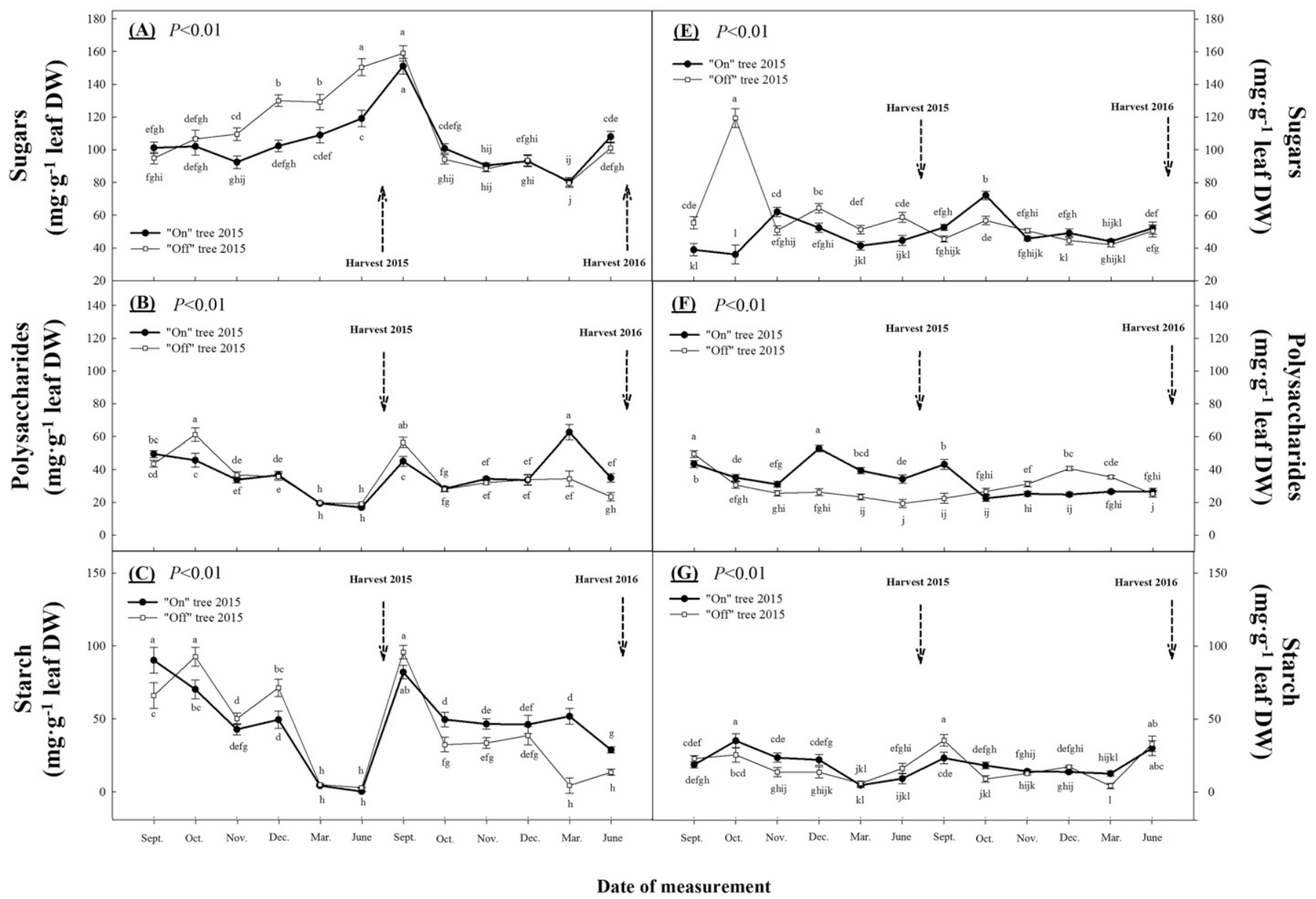

Fig. 3. The seasonal concentrations of different carbohydrate components in leaves and roots of 10-year-old "on" and "off" 'Nadorcott' mandarin trees: (A and E) sugars, $(\mathbf{B}$ and $\mathbf{F})$ polysaccharides, and $(\mathbf{C}$ and $\mathbf{G})$ starch. The arrows indicate the time of harvest for each season. Bars denote sEs of the means and different letters significant differences between values via Fisher's least significant difference test at $P \leq 0.05(n=10)$.

lack of root growth in "on" trees could be explained by a source limitation of carbohydrates due to excessive flowering and fruiting and would be consistent with the competitive theory concerning carbohydrate sinks (Goldschmidt and Golomb, 1982). In this theory, the presence of a powerful carbohydrate sink such as developing flowers and fruit reduces carbohydrate availability to other sinks such as roots. Because roots cannot synthesize their own source of energy, root growth is entirely dependent on carbohydrates from leaves (Pregitzer et al., 2000). Restriction of the phloem transport pathway by girdling, for example, can cause an accumulation of soluble sugar and starch in leaves and result in a reduction in soluble sugar and starch concentration in roots (Li et al., 2003). Excessive fruiting results in a similar effect to that of girdling, but instead of accumulating in leaves, carbohydrates are consumed by flowers and fruit (i.e., under heavy flowering and fruiting conditions), reproductive sinks compete with roots for carbohydrates, and generally win (Goldschmidt and Golomb, 1982). In other fruiting plants, a heavy fruit load forced vines (Vitis vinifera) to accumulate less sugar in roots (Morinaga et al., 2003); in heavy-fruiting apple (Malus domestica), Palmer (1992) reported reduced dry matter partitioning to roots; and in persimmon (Diospyros kaki), root sugar concentration increased $\approx 2$-fold when $80 \%$ of fruit were thinned and $\approx 2$-fold when $100 \%$ of fruit were thinned (Choi et al., 2005). In other alternate bearing-prone evergreens, high root mortality was associated with low root carbohydrate concentration and a heavy fruit load in coffee [Coffea arabica (Nutman, 1933)], and severe chemical thinning of olive fruit increased carbohydrate concentration in roots by $84 \%$ (Bustan et al., 2011). In citrus, allocation of dry matter and root growth were reduced by fruit in 'Washington Navel' sweet orange (Cary, 1970), whereas on the other hand, fruit removal in 'Valencia' sweet orange and 'Satsuma' mandarin trees during spring increased carbohydrate concentration in roots (Duncan and Eissenstat, 1993) and was associated with an increase in root mass density during summer (Duncan and Eissenstat, 1993; Okuda, 2000).

Dovis et al. (2014) and Monerri et al. (2011) showed that heavy-flowering citrus trees require up to four times more photoassimilates than low-flowering trees, and, therefore, under conditions of alternate bearing, root growth could be restricted even more. Indeed, excessive fruiting in 'Kinnow' and 'Murcott' mandarins was reported to completely deplete carbohydrate reserves in roots (Jones et al., 1975) and in 


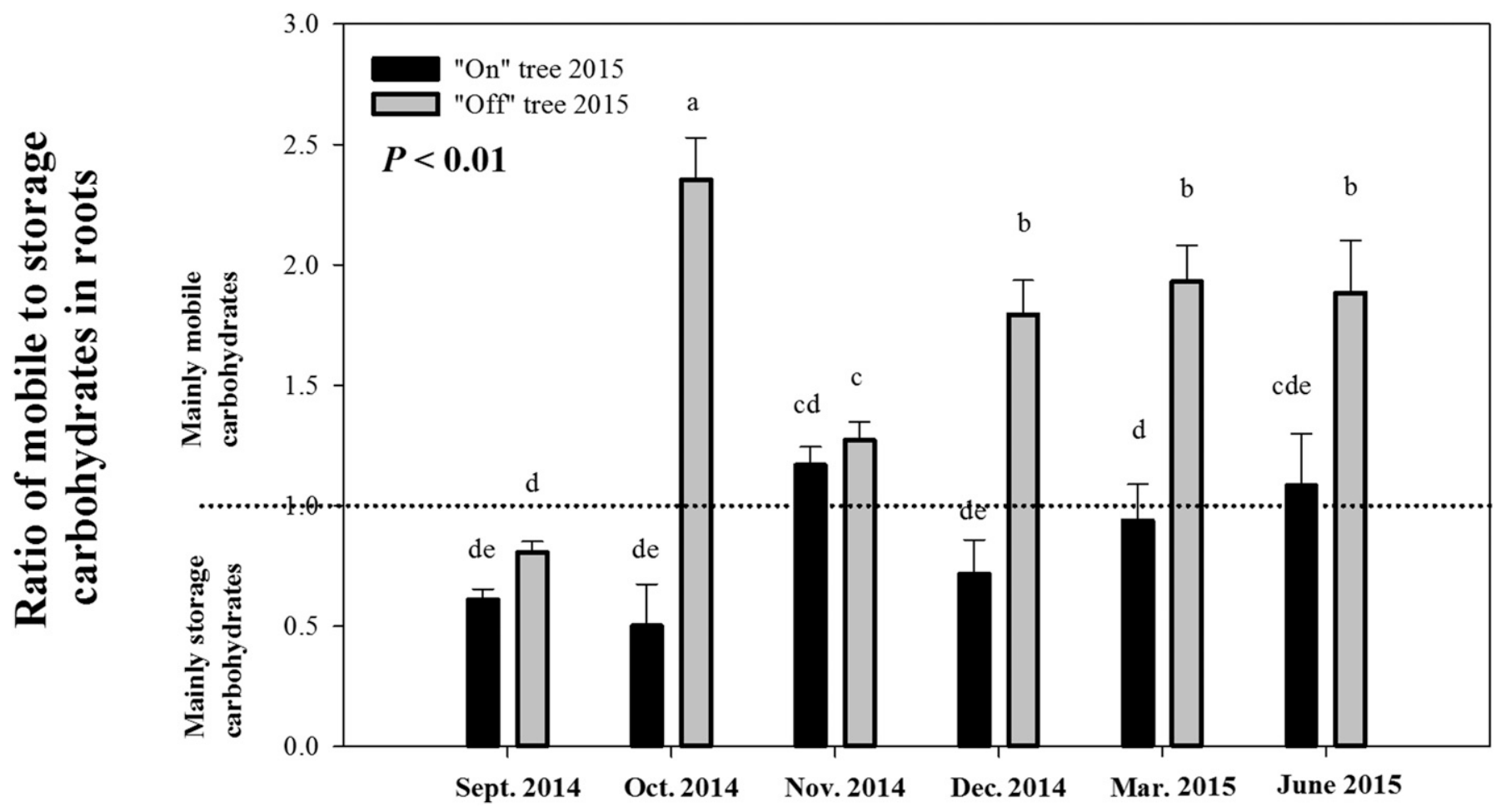

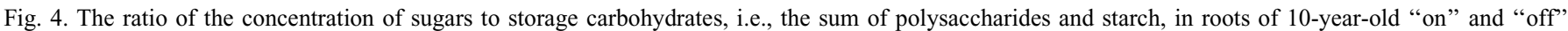
'Nadorcott' mandarin trees. Bars denote sEs of the means and different letters significant differences between values via Fisher's least significant difference test at $P \leq 0.05(n=10)$.

Table 7. The vegetative and reproductive responses to summer and winter branch treatments in 'Nadorcott' mandarin.

\begin{tabular}{|c|c|c|}
\hline & $\begin{array}{l}\text { Vegetative response } \\
\text { (Summer Expt.) } \\
\end{array}$ & $\begin{array}{c}\text { Flowering response } \\
\text { (Winter Expt.) }\end{array}$ \\
\hline Treatment & (shoots/branch) & (flowers/branch) \\
\hline Defruited + girdled & $6.1 \mathrm{a}^{\mathrm{z}}$ & $79 \mathrm{a}$ \\
\hline Fruiting + girdled & $1.6 \mathrm{~b}$ & $7 c$ \\
\hline Defruited & $8.6 \mathrm{a}$ & $34 \mathrm{~b}$ \\
\hline Fruiting & $0.5 \mathrm{~b}$ & $14 \mathrm{bc}$ \\
\hline$P$ value & $<0.01$ & $<0.01$ \\
\hline
\end{tabular}

${ }^{\mathrm{z}}$ Different letters in the same column denote significant differences via Fisher's least significant difference test at $P \leq 0.05(n=8)$.

a severe case, resulted in death of feeder roots (Smith, 1976). In the present study, the profuse number of flowers and fruit in "on" 'Nadorcott' mandarin trees appeared to have consumed the most of the sugars during spring and early summer, limited carbohydrate allocation to roots, and resulted in a subsequent lack of root growth during summer. Root sugar concentration during spring was negatively correlated with total flowers during full bloom $\left[R^{2}=(-) 0.89\right.$ and $R^{2}=(-) 0.69$ in seasons 1 and 2 , respectively $(P<0.001)]$ and with fruit yield in summer [season 1: $R^{2}=(-) 0.62(P<0.010)$; season $2: R^{2}=(-) 0.86(P<$ $0.001)]$. The low flower intensity in "off" trees is associated with an $\approx 3$-fold increase in root sugar concentration during full bloom. Lack of reproductive sinks during this period may have allowed for the distribution of photosynthetically fixed sugars and readily available carbohydrates from leaves to roots. Higher root sugar concentration in "off" trees may partially explain the subsequent spike in early summer root growth, after cessation of the spring vegetative shoot flush and before initiation of the summer vegetative shoot flush, as more carbohydrates were readily available to start and maintain their growth.

Overall, this study confirmed that the lack of vegetative shoot development is a major cause of poor flowering following an "on" year (García-Luís et al., 1995b; Lenz, 1967; Martínez-Alcántara et al., 2015; Monselise and Goldschmidt, 1982), but leaf carbohydrate concentration does not limit summer vegetative shoot development (Verreynne, 2005). Furthermore, the important interdependent relationship between root growth and vegetative shoot flushes in citrus was illustrated by Bevington and Castle (1985) and others (Eissenstat and Duncan, 1992; Mataa and Tominaga, 1998), and the results in the present study for the first time indicate a similar relationship in alternate-bearing citrus trees. The interaction of fruit, roots and vegetative shoots, and the synthesis and accumulation in these tissue types of phytohormone substances should be investigated in further studies on alternate bearing in citrus.

Furthermore, leaf carbohydrate concentration during winter does not appear to be a limiting factor for flowering but does appear to influence the intensity of the subsequent return bloom in "off" crop scenarios only. How it regulates this effect (i.e., by directly upregulating expression of flowering genes or by facilitating floral organogenesis as a source of energy) is not clear. In an "on" crop scenario and during winter, the influence of leaf carbohydrates on flowering is not critical, which concurs with numerous other reports (Cohen, 1981; García-Luís et al., 1995a; Goldschmidt et al., 1985; Jones et al., 1974). The lack of flowering response in an "on" crop scenario cannot be explained by factors other than probable fruit-produced phytohormones, which have been 
Table 8. The effects of branch source/sink alterations in moderate-bearing 'Nadorcott' mandarin trees during summer, at the end of Nov. 2014, and winter, at the end of Apr. 2015, on the concentrations of leaf sugars, leaf polysaccharides, and leaf starch.

\begin{tabular}{|c|c|c|c|c|c|c|c|c|c|c|c|c|}
\hline \multirow[b]{4}{*}{ Treatment } & \multicolumn{5}{|c|}{ Leaf sugars } & \multicolumn{5}{|c|}{ Leaf polysaccharides } & \multicolumn{2}{|c|}{ Leaf starch } \\
\hline & \multicolumn{12}{|c|}{ (mg. $\mathrm{g}^{-1}$ leaf dry weight) } \\
\hline & \multicolumn{12}{|c|}{ Summer Expt. } \\
\hline & 22 Nov. & 4 Dec. & 18 Dec. & 7 Jan. & 22 Nov. & 4 Dec. & 18 Dec. & 7 Jan. & 22 Nov. & 4 Dec. & 18 Dec. & 7 Jan. \\
\hline Fruiting and girdled & 111.4 & $84.6 \mathrm{a}$ & 92.6 & $105.9 \mathrm{a}$ & 68.6 & $141.6 \mathrm{a}$ & $117.4 \mathrm{a}$ & $106.0 \mathrm{a}$ & 96.6 & $151.8 \mathrm{a}$ & $138.8 \mathrm{a}$ & $128.8 \mathrm{a}$ \\
\hline Defruited & 112.4 & $89.3 \mathrm{a}$ & 91.6 & $104.4 \mathrm{a}$ & 55.5 & $98.4 \mathrm{~b}$ & $59.6 \mathrm{~b}$ & $53.7 \mathrm{~b}$ & 78.5 & $110.6 \mathrm{~b}$ & $61.8 \mathrm{~b}$ & $51.2 \mathrm{~b}$ \\
\hline Fruiting & 120.4 & $92.1 \mathrm{a}$ & 91.8 & $105.7 \mathrm{a}$ & 63.8 & $103.0 \mathrm{~b}$ & $65.1 \mathrm{~b}$ & $51.1 \mathrm{~b}$ & 80.5 & $106.0 \mathrm{~b}$ & $64.3 \mathrm{~b}$ & $53.7 \mathrm{~b}$ \\
\hline$P$ value & \multicolumn{12}{|c|}{ Winter Expt. } \\
\hline Treatments & 22 Apr. & 5 May & 19 May & 4 Jun. & 22 Apr. & 5 May & 19 May & 4 Jun. & 22 Apr. & 5 May & 19 May & 4 Jun. \\
\hline Defruited and girdled & 120.1 & $111.1 \mathrm{~b}$ & $120.3 \mathrm{~b}$ & $119.8 \mathrm{~b}$ & 40.3 & 41.3 & $55.5 \mathrm{a}$ & $56.6 \mathrm{a}$ & 34.9 & $81.4 \mathrm{a}$ & $133.0 \mathrm{a}$ & $\overline{165.9 \mathrm{a}}$ \\
\hline Fruiting and girdled & 119.4 & $130.9 \mathrm{a}$ & $134.7 \mathrm{a}$ & $134.7 \mathrm{a}$ & 31.5 & 37.9 & $29.0 \mathrm{~b}$ & $27.3 \mathrm{~b}$ & 38.1 & $5.2 \mathrm{c}$ & $16.3 \mathrm{c}$ & $27.3 \mathrm{~b}$ \\
\hline Defruited & 121.6 & $124.5 \mathrm{a}$ & $127.0 \mathrm{ab}$ & $127.1 \mathrm{a}$ & 34.6 & 35.2 & $29.5 \mathrm{~b}$ & $22.5 \mathrm{~b}$ & 32.9 & $31.1 \mathrm{~b}$ & $42.7 \mathrm{~b}$ & $24.7 \mathrm{~b}$ \\
\hline
\end{tabular}

${ }^{\mathrm{z}}$ Different letters in the same column denote significant differences via Fisher's least significant difference test at $P \leq 0.05$ ( $\left.n=8\right)$.

shown to directly determine flowering response in an upstream event by limiting the expression of citrus flowering genes (García-Luís et al., 1995a; Goldberg-Moeller et al., 2013; Goldschmidt et al., 1985; Koshita et al., 1999; MuñozFambuena et al., 2011).

\section{Conclusions}

Results from this study confirm that the lack of vegetative shoot development in "on" shoots, "on" branches, and "on" trees plays a central role in poor return bloom and in perpetuating the alternate bearing cycle in citrus. The lack of new vegetative shoot development limits the number of new available flowering sites in the subsequent spring. Vegetative shoot development during spring and summer was negatively associated with the presence of fruit but unrelated to leaf gas exchange parameters and leaf carbohydrate concentration. Fruit load and root sugar concentration provided the best correlations with the intensity of the summer vegetative shoot flush. Root sugar concentration peaked during full bloom, and higher root growth activity was observed before periods of increased vegetative shoot development in "off" trees. The early season root sugar concentration was lower and root and shoot growth were absent or lower in "on" trees. The study provides new insights into how fruit load influences vegetative shoot development in alternate-bearing citrus trees: fruit are the major carbohydrate sink and most probably disturb the balance between root growth and vegetative shoot development.

\section{Literature Cited}

Agustí, M., A. Martínez-Fuentes, and C. Mesejo. 2002. Citrus fruit quality. Physiological basis and techniques of improvement. Agrociencia 4:1-16.

Bangerth, K.F. 2009. Floral induction in mature, perennial fruit trees: Similarities and discrepancies with annual/biennial plants and the involvement of plant hormones. Scientia Hort. 122:153-163.

Barnett, J. and E.A. Mielke. 1981. Alternate bearing: A re-evaluation. Pecan South 8:20-30.
Bevington, K.B. and W.S. Castle. 1985. Annual root growth pattern of young citrus trees in relation to shoot growth, soil temperature, and soil water content. J. Amer. Soc. Hort. Sci. 110:840-845.

Brummer, Y. and S.W. Cui. 2005. Understanding carbohydrate analysis, p. 67-104. In: S.W. Cui (ed.). Food carbohydrates, chemistry physical properties, and applications. CRC Press, New York, NY.

Burger, W.T., A.P. Vincent, C.J. Barnard, J.A. du Plessis, and J.H.E. Smith. 1970. Metodes waarvolgens die grootte van sitrusbome bepaal kan word. SA. Citrus J. 433:13-15.

Bustan, A., A. Avni, S. Lavee, I. Zipori, Y. Yeselson, A.A. Schaffer, J. Riov, and A. Dag. 2011. Role of carbohydrate reserves in yield production of intensively cultivated olive (Olea europaea L.) trees. Tree Physiol. 31:519-530.

Cary, P.R. 1970. Growth, yield and fruit composition of 'Washington Navel' orange cuttings as affected by root temperature, nutrient supply and crop load. Hort. Res. 10:20-33.

Choi, S-T., D.S. Park, W.D. Song, and S-M. Kang. 2005. Effect of thinning degrees on fruit characteristics and carbohydrate accumulations of persimmon trees defoliated in early autumn. Acta Hort. 685:105-112.

Cohen, A. 1981. Recent developments in girdling of citrus trees. Proc. Intl. Soc. Citricult. 1:196-199.

Dag, A., A. Bustan, A. Avni, I. Tzipori, S. Lavee, and J. Riov. 2010. Timing of fruit removal affects concurrent vegetative growth and subsequent return bloom and yield in olive (Olea europaea L.). Scientia Hort. 123:469-472.

Davenport, T.L. 2000. Principles of climatic effects on flowering in citrus. Proc. Intl. Soc. Citricult. 1:289-291.

Dovis, V.L., E.C. Machado, R.F. Ribeiro, J.R. Magalháes Filho, P.E.R. Marchiori, and C.R.G. Sales. 2014. Roots are important sources of carbohydrates during flowering and fruiting in 'Valencia' sweet orange trees with varying fruit load. Scientia Hort. 174:87-94.

Duncan, L.W. and D.M. Eissenstat. 1993. Responses of Tylenchulus semipenetrans to citrus fruit removal: Implications for carbohydrate competition. J. Nematol. 25:7-14.

Eissenstat, D.M. and L.W. Duncan. 1992. Root growth and carbohydrate responses in bearing citrus trees following partial canopy removal. Tree Physiol. 10:245-257.

García-Luís, A., F. Fornés, and J.L. Guardiola. 1995b. Leaf carbohydrates and flower formation in Citrus. J. Amer. Soc. Hort. Sci. 120:222-227.

García-Luís, A., M. Kanduser, and J.L. Guardiola. 1995a. The influence of fruiting on the bud sprouting and flower induction responses to chilling in Citrus. J. Hort. Sci. 70:817-825. 
Goldberg-Moeller, R., L. Shalom, L. Shlizerman, S. Samuels, N. Zur, R. Ophir, E. Blumwald, and A. Sadka. 2013. Effects of gibberellin treatment during flowering induction period on global gene expression and the transcription of flowering-control genes in citrus buds. Plant Sci. 198:46-57.

Goldschmidt, E.E. 1999. Carbohydrate supply as a critical factor for citrus fruit development and productivity. HortScience 34:1020-1024.

Goldschmidt, E.E., N. Aschkenazi, Y. Herzano, A.A. Schaffer, and S.P. Monselise. 1985. A role for carbohydrate levels in the control of flowering in citrus. Scientia Hort. 26:159-166.

Goldschmidt, E.E. and A. Golomb. 1982. The carbohydrate balance of alternate bearing citrus trees and the significance of reserves for flowering and fruiting. J. Amer. Soc. Hort. Sci. 107:206-208.

Gur, A., R.M. Samish, and D. Zamet. 1969. A comparison of different planting distances for apple trees. Isr. J. Agr. Res. 19:79-86.

Hield, H.Z. and R.H. Hilgeman. 1969. Alternate bearing and chemical fruit thinning of certain citrus varieties. Proc. Intl. Soc. Citricult. $3: 1145-1153$.

Iwasaki, T. and A. Owada. 1960. Studies of the control of alternate bearing. II. The effect of environmental conditions during winter on the number of flowers and growth of shoots. J. Hort. Assn. Jpn. 29:37-46.

Jones, W.W., T.W. Embleton, E.L. Barnhart, and C.B. Cree. 1974. Effect of time and amount of fruiting on leaf carbohydrates and fruit set in 'Valencia' oranges. Hilgardia 42:441-450.

Jones, W.W., T.W. Embleton, and C.W. Coggins, Jr. 1975. Starch content of roots of 'Kinnow' mandarin trees bearing fruit in alternate years. HortScience 10:514.

Koshita, Y., T. Takahara, T. Ogata, and A. Goto. 1999. Involvement of endogenous plant hormones (IAA, ABA, GAs) in leaves and flower bud formation of Satsuma mandarin (Citrus unshiu Marc.). Scientia Hort. 79:185-194.

Krajewski, A. and E. Rabe. 1995a. Citrus flowering: A critical review. J. Hort. Sci. 70:357-374.

Krajewski, A. and E. Rabe. 1995b. Effect of heading and its timing on flowering and vegetative shoot development in 'Clementine' mandarin (Citrus reticulata Blanco). J. Hort. Sci. 70:445-451.

Lenz, F. 1967. Relationship between the vegetative and reproductive growth of 'Washington Navel' orange cuttings (Citrus sinensis L. Osbeck). J. Hort. Sci. 42:31-39.

Li, C-Y., D. Weiss, and E.E. Goldschmidt. 2003. Girdling affects carbohydrate-related gene expression in leaves, bark and roots of alternate-bearing citrus trees. Ann. Bot. 92:137-143.

Malik, N.S.A., J.L. Perez, and M. Kunta. 2015. Inducing flushing in citrus cultivars and changes in polyphenols associated with bud break and flowering. J. Hort. 2:148.

Martínez-Alcántara, B., D.J. Iglesias, C. Reig, C. Mesejo, M. Agustí, and E. Primo-Millo. 2015. Carbon utilization by fruit limits shoot growth in alternate-bearing citrus trees. J. Plant Physiol. 176:108-117. Mataa, M. and S. Tominaga. 1998. Effects of root restriction on tree development in Ponkan mandarin (Citrus reticulata Blanco). J. Amer. Soc. Hort. Sci. 123:651-655.

Monerri, C., A. Fortunato-Almeida, R.V. Molina, S.G. Nebauer, A. García-Luís, and J.L. Guardiola. 2011. Relation of carbohydrate reserves with the forthcoming crop, flower formation and photosynthetic rate, in the alternate bearing 'Salustiana' sweet orange (Citrus sinensis L.). Scientia Hort. 129:71-78.

Monselise, S.P. and E.E. Goldschmidt. 1982. Alternate bearing in fruit trees. Hort. Rev. 4:128-173.

Monselise, S.P., E.E. Goldschmidt, A. Golomb, and R. Rolf. 1983. Alternate bearing in citrus: Long-term effects of a single girdling treatment on individual 'Michal' tangerine branches. J. Amer. Soc. Hort. Sci. 108:373-376.

Morinaga, K., S. Imai, H. Yakushiji, and Y. Koshita. 2003. Effects of fruit load on partitioning of ${ }^{15} \mathrm{~N}$ and ${ }^{13} \mathrm{C}$, respiration, and growth of grapevine roots at different fruit stages. Scientia Hort. 97:239-253.

Moss, G.I., J. Bellamy, and K.B. Bevington. 1974. Controlling biennial bearing. Austral. Citrus News 50:6-7.

Muñoz-Fambuena, N., C. Mesejo, M.C. González-Mas, E. PrimoMillo, M. Agustí, and D.J. Iglesias. 2011. Fruit regulates seasonal expression of flowering genes in alternate-bearing 'Moncada' mandarin. Ann. Bot. 108:511-519.

Nadori, E.B. 2006. Nadorcott mandarin: A promising new variety. Proc. Intl. Soc. Citricult. (2004). 1:356-359.

Nutman, F.J. 1933. The root system of Coffea arabica L. I. Root systems in typical soils of British East Africa. Empire J. Expt. Agr. 1:271-284.

Okuda, H. 2000. A comparison of IAA and ABA levels in leaves and roots of two citrus cultivars with different degrees of alternate bearing. J. Hort. Sci. Biotechnol. 75:355-359.

Palmer, J.W. 1992. Effects of varying crop load on photosynthesis, dry matter production and partitioning of Crispin/M.27 apple trees. Tree Physiol. 11:19-33.

Pregitzer, K.S., J.S. King, A.J. Burton, and S.S. Brown. 2000. Responses of tree fine roots to temperature. New Phytol. 147:105-115.

Rabe, E. and P.J.J. Van Rensburg. 1996. Gibberellic acid sprays, girdling, flower thinning and potassium applications affect fruit splitting and yield in the 'Ellendale' tangor. J. Hort. Sci. 71:195-203.

Rivas, F., Y. Erner, E. Alós, M. Juan, V. Almela, and M. Agustí. 2006. Girdling increases carbohydrate availability and fruit-set in citrus cultivars irrespective of parthenocarpic ability. J. Hort. Sci. Biotechnol. 81:289-295.

Schaffer, A.A., E.E. Goldschmidt, R. Goren, and D. Galili. 1985. Fruit set and carbohydrate status in alternate and non-alternate bearing citrus cultivars. J. Amer. Soc. Hort. Sci. 110:574-578.

Shalom, L., S. Samuels, N. Zur, L. Shlizerman, A. Doron-Faigenboim, E. Blumwald, and A. Sadka. 2014. Fruit load induces changes in global gene expression and in abscisic acid (ABA) and indole acetic acid (IAA) homeostasis in citrus buds. J. Expt. Bot. 65:3029-3044. Shalom, L., S. Samuels, N. Zur, L. Shlizerman, H. Zemach, M. Weissberg, R. Ophir, E. Blumwald, and A. Sadka. 2012. Alternate bearing in citrus: Changes in the expression of flowering control genes and in global gene expression in $\mathrm{ON}$ - versus OFF-crop trees. PLoS One 7:e46930.

Smith, P.F. 1976. Collapse of 'Murcott' tangerine trees. J. Amer. Soc. Hort. Sci. 101:23-25.

Southwick, S.M. and T.L. Davenport. 1987. Modification of the water stress-induced floral response in 'Tahiti' lime. J. Amer. Soc. Hort. Sci. 112:231-236.

Stander, O.P.J., G.H. Barry, and P.J.R. Cronjé. 2017. Fruit-loadinduced starch accumulation causes leaf chlorosis in 'Nadorcott' mandarin. Scientia Hort. 222:62-68.

Stander, O.P.J., J. Botes, and C. Krogscheepers. 2018. The potential for use of metamitron as a chemical fruit thinning agent in mandarin. HortTechnology 28:28-34.

Stander, O.P.J. and P.J.R. Cronjé. 2016. Reviewing the commercial potential of hand thinning in citrus with a cost-benefit analysis of summer hand thinning of 'Nadorcott' mandarin. HortTechnology 26:206-212.

Syvertsen, J.P., C. Goni, and A. Otero. 2003. Fruit load and canopy shading affect leaf characteristics and net gas exchange of 'Spring' navel orange trees. Tree Physiol. 23:899-906.

Verreynne, J.S. 2005. The mechanism and underlying physiology perpetuating alternate bearing in 'Pixie' mandarin (Citrus reticulata Blanco). Univ. California, Riverside, PhD Diss.

Verreynne, J.S. and C.J. Lovatt. 2009. The effect of crop load on bud break influences return bloom in alternate bearing 'Pixie' mandarin. J. Amer. Soc. Hort. Sci. 34:299-307. 